Research Article

\title{
Investigation of Chlorophyl-a Derived Compounds as Photosensitizer for Photodynamic Inactivation
}

\author{
Listiana Oktavia ${ }^{1, *}$, Irma Mulyani ${ }^{2}$, Veinardi Suendo ${ }^{2,3}$ \\ ${ }^{1}$ Research Center for Chemistry, Indonesian Institute of Sciences (LIPI), 16911, Indonesia. \\ 2Inorganic and Physical Chemistry Research Division, Institut Teknologi Bandung, 40132, Indonesia. \\ ${ }^{3}$ Research Center for Nanoscience and Nanotechnology, Institut Teknologi Bandung, 40132, Indonesia.
}

Received: 8h $^{\text {th }}$ February 2021; Revised: $16^{\text {th }}$ March 2021; Accepted: 17th March 2021

Available online: 18 ${ }^{\text {th }}$ March 2021; Published regularly: March 2021

\section{Abstract}

Chlorophyll has unique physicochemical properties which makes them good as photosensitizer of Photodynamic Inactivation (PDI). The physicochemical properties of chlorophyll as photosensitizer can be optimized through several routes. One of the possible route is by replacing the metal ion center of chlorophyll with other ions. In this research, the effect of coordinated metal ion in the natural chlorophyll-a was studied for bacterial growth $(S$. aureus) inhibition. The replacement of metal in the center of chlorophyll hopefully can improve the intensity of Intersystem Crossing Mechanism (ISC) lead to the formation of singlet oxygen species. The chlorophyll a and b were isolated from spinach via precipitation technique using 1,4 dioxane and water. The chlorophyll a and b were separated using sucrose column chromatography. The thin layer chromatography result showed that chlorophyll a $\left(R_{f}\right.$ : 0.57$)$ had been well separated with chlorophyll b $\left(R_{f}\right.$. 0.408). The absorption spectra of chlorophyll a and b showed that the Soret band was observed at 411 and $425 \mathrm{~nm}$, while the Q band appeared at 663 and $659 \mathrm{~nm}$. Replacement of metal ion center shifted the Soret band of chlorophyll a derivatives to lower energy region, while Q-band was slightly shifted to the higher energy region. The absorption and the fluorescence intensity were also observed decreasing after ion replacement. The Inhibition activity investigation over S. aureus showed the highest inhibition activity was exhibited by Zn-pheophytin-a (66.8\%) followed by chlorophyll a (30.1\%) and Cu-pheophytin-a (0\%). The inhibition activity is correlated with decreasing fluorescence intensity. The formation of singlet oxygen by ISC mechanism is hypothesized to deactivate the excitation state of $\mathrm{Cu}$-pheophytin-a.

Copyright (C) 2021 by Authors, Published by BCREC Group. This is an open access article under the CC BY-SA License (https://creativecommons.org/licenses/by-sa/4.0).

Keywords: Chlorophyll a; Pheophytin; Photosensitizer; Photodynamic inactivation; Sucrose

How to Cite: L. Oktavia, I. Mulyani, V. Suendo (2021). Investigation of Chlorophyl-a Derived Compounds as Photosensitizer for Photodynamic Inactivation. Bulletin of Chemical Reaction Engineering \& Catalysis, 16(1), 161-169 (doi:10.9767/bcrec.16.1.10314.161-169)

Permalink/DOI: https://doi.org/10.9767/bcrec.16.1.10314.161-169

\section{Introduction}

Antibiotics are used to control, treat, or prevent bacterial infection, however, in the recent year, anti-bacterial resistance phenomenon is becoming more of a problem in combating the infectious disease caused by bacteria [1]. To re-

* Corresponding Author

Email: listi004@lipi.go.id /

oktavialisti@gmail.com (L. Oktavia) straint this emerging public health problem, it is important to develop a non-toxic treatment that acts more effectively than current antibiotic treatment [2-4]. One of these effective methods is Photodynamic therapy for bacterial inactivation or widely known as Photodynamic Inactivation (PDI) [5,6]. In addition, PDI was reported to exhibit a fast and effective approach to inactivate multi-resistant bacteria. The in vitro studies showed the possibility of bacterial 
reduction up to $6-\log 10^{6} \mathrm{CFU}$ within seconds during the incubation and irradiation [7].

The bacterial treatment using PDI is a treatment that use the light-sensitive material, photosensitizer (PS) along with visible or ultraviolet light to produce singlet oxygen $\left({ }^{1} \mathrm{O}_{2}\right)$ and radical species that induces phototoxic damage to the bacterial cell immediately during the irradiation $[8,9]$. The toxic singlet oxygen can be produced when the PS is irradiated with the appropriate light with a particular wavelength (visible or UV light) that led to the excitation of PS ground state. The excited single state is unstable and lives for less than $1 \mu \mathrm{s}$. It can return back to the ground state via emission of a secondary photon in the form of fluorescence or it can undergo intersystem crossing into the excited triple-state to produce singlet oxygen species [10]. The PS triple-state can produce the chemical changes in the bacterial cell via two competitive pathways (type 1 and type II) [2]. Type I reaction produces radical ions that can pass quickly through cell membranes causing the detrimental damage to the bacteria cell [11]. Type II reaction is characterized by the presence of appropriate oxygen concentration. The triple state of PS can transmit its energy directly to the triplet ground state of molecular Oxygen found mostly in the cells [12]. The transmitted energy gained by triple state oxygen molecule $\left({ }^{3} \mathrm{O}_{2}\right)$ excites the ground state of ${ }^{3} \mathrm{O}_{2}$ to produce singlet oxygen $\left({ }^{1} \mathrm{O}_{2}\right)[13,14]$. PDI relies on the production of ${ }^{1} \mathrm{O}_{2}$ by type II reaction as the predominant cytotoxic ROS (Reactive Oxygen Species) that has significant lethal effect [15].

The PDI technique exhibits some advantages for the treatment of microbial infections such as a broad spectrum of actions compared to the antibiotics, the efficient inactivation of antibiotic-resistant strains, the low mutagenic potential, and the absence of selection of the photo-resistant microbial cells $[9,16]$. Kasfer and Hamblin [17] mentioned that the development of resistance to PDI treatment is unlikely due to the short duration of treatment and the photo-generated ROS could attack multiple cellular targets. The tolerance enhancement of bacteria to PDI is considered caused by the induction of genes responsible for defense against oxidative stress [8]. Furthermore, the absence of specific defense systems against singlet oxygen in the organism is also explained for the reason why PDI is less possible to develop resistance strain [18]. Another study [19] proposed that repeated exposure of $E$. coli and $S$. aureus to $\mathrm{ZnTnHex-2-Pyp} \mathrm{(photosensitizer),}$ did not change the tolerance of the microbes for the PS.

The PDI efficacy depends on the photosensitizer (PS) material. The most appropriate photosensitizer is characterized as positivelycharged, water-soluble and photo-stable [7]. Many PS have been introduced for the treatment ranging from synthetic PS to naturally available PS. One class of PS attracting many researchers is naturally occurring porphyrintype compound. The porphyrin nucleus contains $22 \pi$ electrons, with $18 \pi$ electrons delocalized the macrocycle. Since their aromatic properties, porphyrins commonly participate in electrophilic substitution reaction at the meso positions, which possess the most electron density, as such, are also the most reactive [2]. As the compliance of the delocalized electrons, porphyrins show have very intense absorption bands in the visible region which is favorable properties as PS for PDI. Porphyrins possess a good amphiphilicity and ability for numerous chemical modifications [20]. Porphyrin molecules were reported to produce high quantum yield of ${ }^{1} \mathrm{O}_{2}$ production and high one-photon absorption coefficient $\left(\approx 500,000 \mathrm{M}^{-1} \cdot \mathrm{cm}^{-1}\right)$ [21]. Moreover, porphyrins were reported to possess a high binding affinity to cellular components, membranes, proteins, and DNA [22,23].

One of the prominent natural porphyrintype molecules is chlorophyll. The most abundant and widely distributed green pigment in green plants, chlorophyll, has been studied in decades for its unique physicochemical properties $[24,25]$. Moreover, The wide range of absorption spectrum of chlorophyll and chlorophyll derivative (CD) compounds, high absorption spectra at the range of $400-800 \mathrm{~nm}$, high rate of ROS production and easy chemical modification make chlorophyll appropriate to be investigated for the next potential PS for PDI $[26,27]$. Chemical modifications either by ion center replacement or hydrophobic group (phytyl group) substitution were reported to generate the chlorophyll derivatives that have more beneficial properties for PDI photosensitizer [25].

In this study, the potency of natural chlorophyll-a and its derivatives will be evaluated as PS for photodynamic Inactivation (PDI). The $\mathrm{Mg}^{2+}$ ion in the center of the chlorophyll (Figure 1) will be replaced with $\mathrm{Zn}^{2+}$ and $\mathrm{Cu}^{2+}$ and the antimicrobial effect of those CDs will be evaluated. Ion $\mathrm{Cu}$ and $\mathrm{Zn}$ were chosen in this experiment since the ion size of both ions is similar enough with $\mathrm{Mg}^{2+}$. In addition, the chemical stability of the porphyrin-metal ion 
complex is also considered for ion replacement [25]. Moreover, the previous study reported $\mathrm{Zn}$ porphyrin complex generated more ${ }^{1} \mathrm{O}_{2}$ compare to its parent compound [28,29]. The unusual chlorophyll-a isolation was also introduced here, we applied sucrose column chromatograph instead of silica for the stationary phase [30]. This study hopefully can be a preliminary study for exploring the potency of natural chlorophyll for photosensitizer of Photodynamic Inactivation.

\section{Materials and Methods}

\subsection{Extraction and Isolation of Chlorophyll a}

The commercially available green spinach (Amarantus tricolor L.) was immersed in cold acetone $\left(\mathrm{C}_{3} \mathrm{H}_{6} \mathrm{O}\right)$ (Merck) and was mashed up by the mechanic blender creating the green slurry suspension. The crude chlorophyll was obtained by precipitation of spinach residue with distilled water (1/4 from the total volume) and 1,4-dioxane (1/8 from the total volume) (Merck) and let to settle for 7 days at $-20{ }^{\circ} \mathrm{C}$. This precipitation process was repeated 2 times. The precipitated material then was separated and diluted with acetone. The crude extract was obtained by removing the solvent with reduced pressure evaporation.

The chlorophyll a was isolated by column chromatography using manually powdered sucrose $\mathrm{C}_{12} \mathrm{H}_{22} \mathrm{O}_{11}$ (commercial sucrose) as a stationary phase. The mobile phase system was used petroleum ether $\mathrm{C}_{6} \mathrm{H}_{14}$ (Merck) followed by $10 \%$ diethyl ether $\left(\mathrm{C}_{2} \mathrm{H}_{5}\right)_{2} \mathrm{O}$ (Merck) in petroleum ether. The collected fraction was separated from the solvent by reduce pressure evaporation.

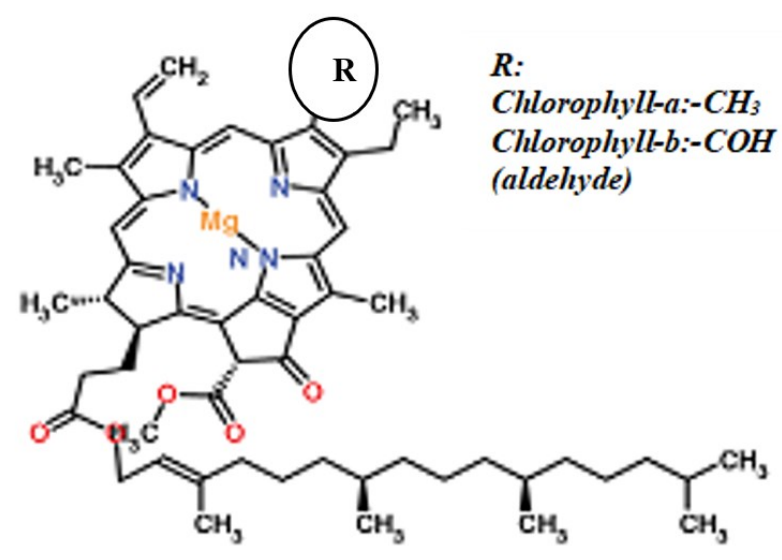

Figure 1. The chemical structure of chlorophyll a and b which are different by methyl and aldehyde. Pheophytin-a is chlorophyll structure without $\mathrm{Mg}^{2+}$ in the center and just replaced by 2 hydrogen. (Adopted from [31]).

\subsection{Zn-pheophytin-a (Zn-Pa) Synthesis}

Isolated chlorophyll-a (Cla) (200 mg) was diluted with acetone $(150 \mathrm{~mL})$ and mixed gently with $10 \mathrm{~mL}$ of Hydrochloric acid ( $\mathrm{HCl} \mathrm{37 \% ,}$ Merck) 0.1 M. The mixture was mixed for 30 minutes at $40{ }^{\circ} \mathrm{C}$ to form $\mathrm{Mg}^{2+}$-free chlorophylla, pheophytin-a. Hexane (Merck) was used to extract pheophytin-a from the mixture. Collected pheophytin-a (20 mg) diluted in chloroform $\left(\mathrm{CHCl}_{3}, \mathrm{Merck}\right)$ was mixed with Zinc acetate dihydrate $\left(\left(\mathrm{ZnCH}_{3} \mathrm{CO}_{2}\right)_{2} .2 \mathrm{H}_{2} \mathrm{O}\right.$, Merck) in methanol. The mixture was stirred at $40{ }^{\circ} \mathrm{C}$ under nitrogen atmosphere for $1 \mathrm{~h}$. After removing chloroform-methanol solvent, the residue was extracted with hexane $\left(\mathrm{C}_{6} \mathrm{H}_{14}\right.$, Merck) and the extract was washed 2 times with distilled water. The hexane was removed by rotary evaporator at $40{ }^{\circ} \mathrm{C}$ to obtain $\mathrm{Zn}-\mathrm{Pa}$ [32]. The purification of $\mathrm{Zn}-\mathrm{Pa}$ was used TLC preparative method using silica plates (TLC Silica Gel 60 $\mathrm{F}_{254}$, Merck) and hexane:acetone 7:3 as a mobile phase.

\subsection{Cu-Pheophytin-a (Cu-Pa) Synthesis}

The Cu-pheophytin-a was prepared by inserting the $\mathrm{Cu}$ (II) to pheophytin-a. The preparation of pheophytin-a was similiar as described above. Pheophytin-a was added with copper chloride dihydrate $\left(\mathrm{CuCl}_{2} .2 \mathrm{H}_{2} \mathrm{O}\right.$, Merck) and acetate buffer $\mathrm{pH}$ 5. The reaction was conducted by reflux for $3 \mathrm{~h}$ at the room temperature under nitrogen atmosphere. The reaction generated two separated phase. The bottom layer was collected and the solvent was removed by rotary evaporatory. The purification was also conducted by preparative TLC as described above.

\subsection{Photo-physical Properties Characterization}

The absorption spectra of CDs was measured by single beam visible and UV/Visible Spectrophotometer Jenway 6305 and sample was diluted in chloroform. The absorption measurement was conducted from 350-700 $\mathrm{nm}$. The fluorescence spectra was investigated at the wavelength $(\lambda)$ 430-800 $\mathrm{nm}$ using Spectrofluorophotometer RF-5301 (Shimadzu Europe). Methanol (Methanol for analysis, Merck) was used to diluted the sample. The observed Soret band maxima was chosen as the excitation wavelength for each sample.

\subsection{Bioactivity Investigation of CDs}

Bioactivity investigation was carried out based on the method described [33] using $S$. aureus culture in Nutrient Broth (NB) medium 
containing peptone (NB for microbiology, Merck), yeast extract, sodium chloride $(\mathrm{NaCl}$ $\geq 99 \%$, Merck). In brief, from a calibrated inoculum at $108 \mathrm{CFU} / \mathrm{mL}$, a volume of $50 \mu \mathrm{L}$ was transferred to an test tube containing $950 \mu \mathrm{L}$ of $\mathrm{CDs}$ at concentration $40 \mu \mathrm{g} / \mathrm{L}$ diluted with aqueous Tween ${ }^{\circledR} 80$ (Polisorbat, Merck) 1\% (wt/vol). Aliquots of $500 \mu \mathrm{L}$ of each suspension were transferred to the test tube for irradiation, and the remaining $500 \mu \mathrm{L}$ sample was used as non-irradiated sample. The irradiation process was conducted using Natrium lamp $(\lambda$ : $650 \mathrm{~nm}$ ) using intensity $2000 \mathrm{lux} / \mathrm{cm}^{2}$ for 30 minutes. During irradiation, oxygen was added to the samples. After irradiation, each sample

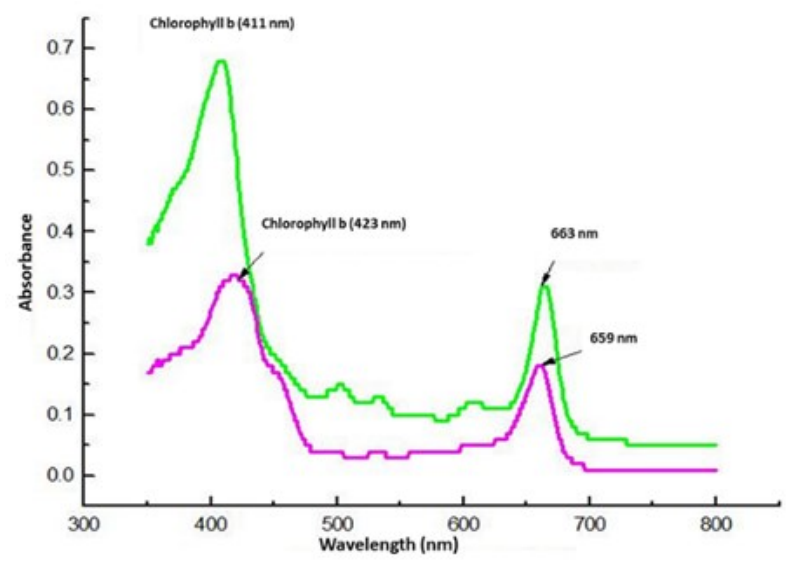

Figure 2: The absorption spectra of $\mathrm{Cla}$ (chlorophyll-a) and Clb (chlorophyll-b) in chloroform.

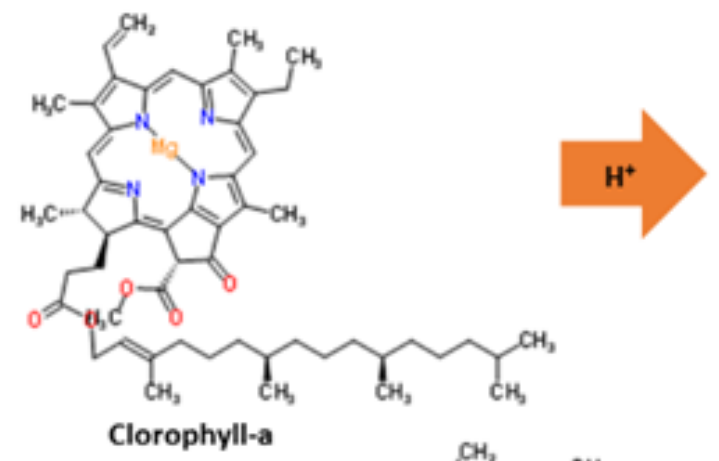

was adjusted with $\mathrm{NB}$ to create $4 \times 10^{4} \mathrm{CFU} / \mathrm{mL}$ of bacteria. The diluted inoculum $(50 \mu \mathrm{L})$ was plated in Nutrient Agar (NA) for $24 \mathrm{~h}$ for incubation at $37{ }^{\circ} \mathrm{C}$, and the $\mathrm{CFU}$ number was counted. The same experiment was carried out for control groups using the same amount of inoculum and $1.0 \%$ aqueous Tween 80 solution without CDs. The control group without any treatment was considered as $0 \%$ of death.

\section{Results and Discussions}

The green spinach was chosen due to its abundant, easy to get and relatively low price natural sources. The cold precipitation technique by addition of 1,4 dioxane and water is to optimize the chlorophyll extraction by formation of chlorophyll-dioxane complex and to eliminate the unnecessary pigments and plant materials. Chlorophyll a, b and $\beta$-carotene are known as major pigments from green spinach leaves [34]. The chlorophyll a (Cla) was chosen for future treatment since its higher availability in the natural sources compared to chlorophyll $\mathrm{b}(\mathrm{Clb})$ and also $\mathrm{Cla}$ is reported to be more photostable. The yield of the crude extract from green spinach was $1.4 \%$.

The supersensitive column chromatography with sucrose as stationary phase was performed. It was conducted since slight polarity difference between $\mathrm{Cla}$ and $\mathrm{Clb}$. Sucrose column chromatography was reported successful to separate chlorophyll a from other pigments

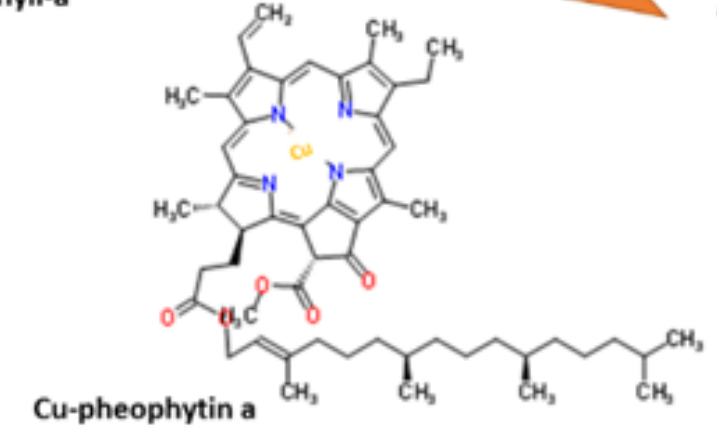
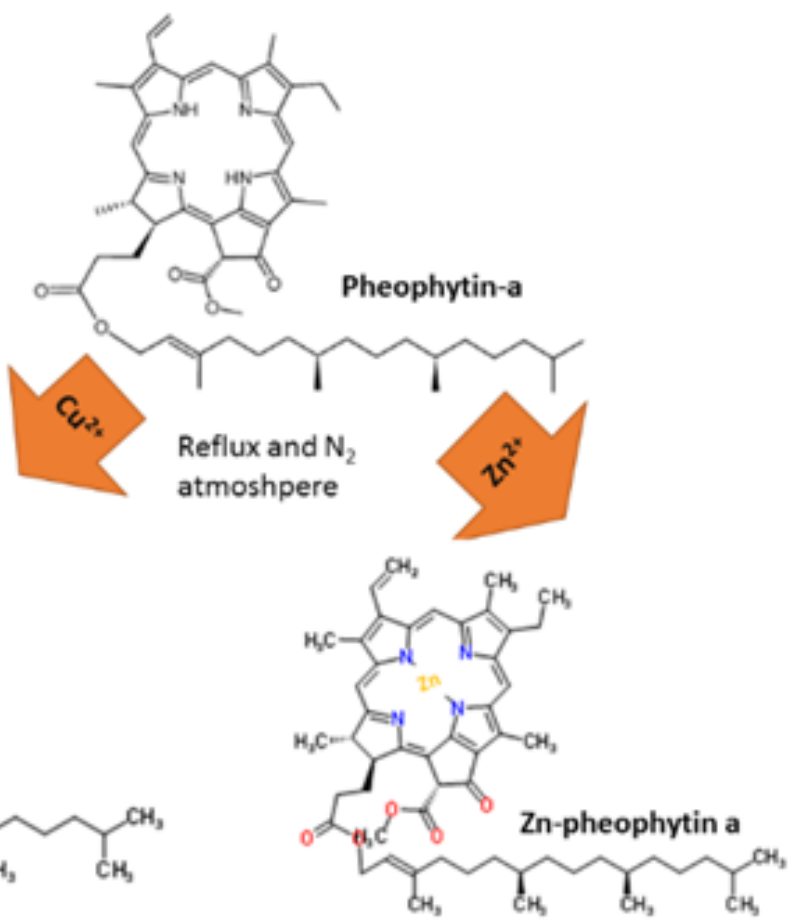

Figure 3. Synthesis route of $\mathrm{Zn}-\mathrm{Pa}$ and $\mathrm{Cu}-\mathrm{Pa}$. 
from spinach extract [35]. The elution order was applied according to the polarity of the target compounds. $\beta$-carotene is the most non polar compound, $\beta$-carotene in yellow color came out first from the column followed by Cla (dark green) and the last pigment was Clb (lightgreen). The appearance of one spot after TLC observation indicated the purity of the isolated compounds. The retention factor $\left(R_{f}\right)$ is 0.571 and 0.408 for $\mathrm{Cla}$ and $\mathrm{Clb}$, respectively. Figure 2 described the absorption spectra of isolated $\mathrm{Cla}$ and $\mathrm{Clb}$.

Cla exhibited the maxima peak at $411 \mathrm{~nm}$ (Soret band) and $663 \mathrm{~nm}$ (Q band), while for $\mathrm{Clb}$, the maxima peak appeared at $423 \mathrm{~nm}$ (Soret band) and $659 \mathrm{~nm}$ (Q band). The difference maxima peak showed that $\mathrm{Cla}$ and $\mathrm{Clb}$ were separated. Cla and $\mathrm{Clb}$ showed good absorption ability in the $400-800 \mathrm{~nm}$. This physicochemical property is an essential characteristic for PS. At the same concentration, Cla exhibited higher absorption intensity that $\mathrm{Clb}$, as

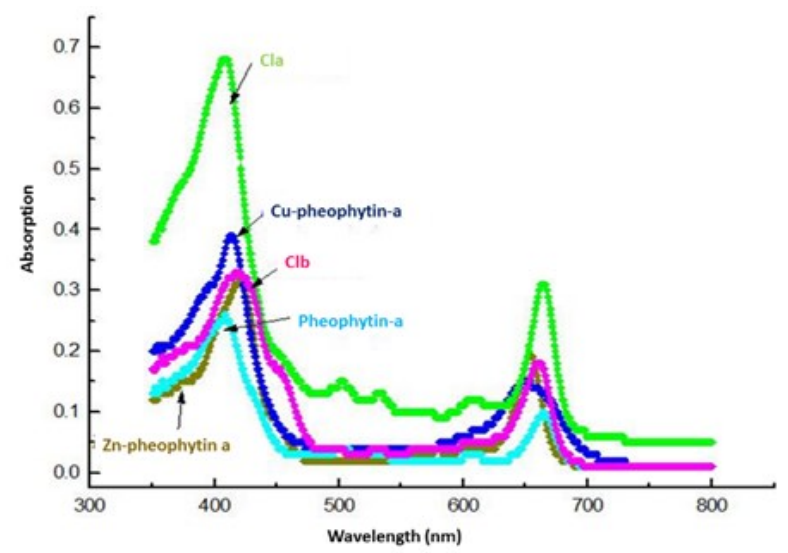

Figure 4. Absorption spectra of $\mathrm{Cla}, \mathrm{Clb}$, and all CDs in chloroform.

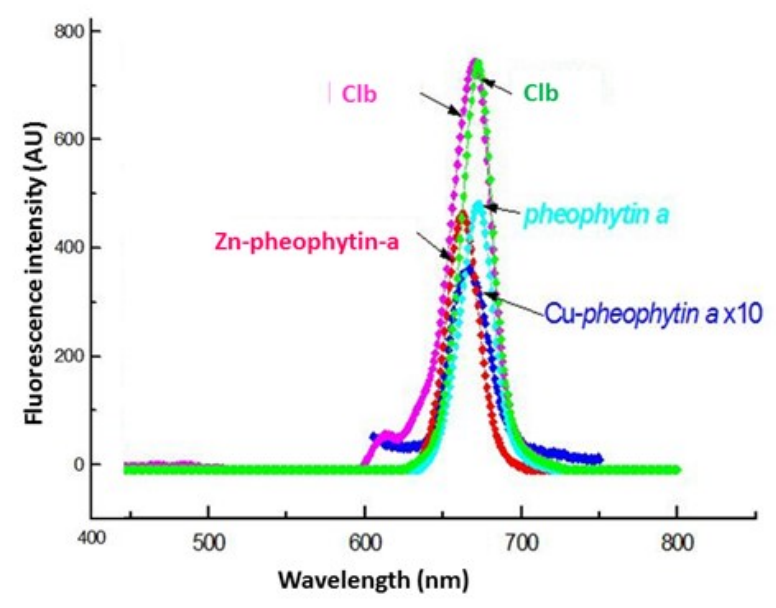

Figure 5. Absorption spectra of $\mathrm{Cla}, \mathrm{Clb}$, and all CDs in methanol. one of the ideal PS requirements is the high absorption ability in the visible wavelength. According to the absorption analysis, Cla was showed more beneficial properties compared to $\mathrm{Clb}$, thus in this study, the modified chlorophyll compounds are derived from Cla.

The replacement of metal ion center of $\mathrm{Cla}$ was purposed to improve the physicochemical properties and chemical stability of Cla. Hydrochloric acid addition to Cla releases $\mathrm{Mg}^{2+}$ from the center and turned to pheophytin-a as pictured in Figure 3. Metal insertion finally was proceed under inert reaction $\left(\mathrm{N}_{2}\right.$ atmosphere) by addition of $\mathrm{Zu}$ and $\mathrm{Cu}$ ion in their salt form.

The physicochemical properties of CDs were evaluated by absorption and fluorescence spectra. The electronic absorption spectra pattern of CDs as depicted in Figure 4 were almost similar to the chlorophyll a. That indicates the presence of the same chromophore on CDs. The ion replacement gives an impact to their absorption intensity. As shown in the Figure 3, the absorption intensity of Cla was the highest among other $\mathrm{CDs}$ and then followed by $\mathrm{Cu}-\mathrm{Pa}$, $\mathrm{Zn}-\mathrm{Pa}, \mathrm{Clb}$ and pheophytin-a (pheo-a). The decrement of absorption intensity might be related with the photobleaching of the CDs [17,30].

The replacement of $\mathrm{Mg}^{2+}$ from Cla obviously shifted the Soret peak to the lower energy area, while Q maxima peak was observed to shift to the higher energy as written in the Table 1. The absence of the ion center in the chlorophyll (pheo-a) shifted the Soret peak to $421 \mathrm{~nm}$. Cu$\mathrm{Pa}$ and $\mathrm{Zn}-\mathrm{Pa}$ exhibited the Soret peak at 414 $\mathrm{nm}$ and $420 \mathrm{~nm}$, respectively. The paramagnetic properties of $\mathrm{Cu}$ might change the electron delocalization on the porphyrin, so thus the Soret peak of $\mathrm{Cu}-\mathrm{Pa}$ comes to a higher energy than $\mathrm{Zn}-\mathrm{Pa}$. The $\mathrm{Q}$ peak of Pheo-a, $\mathrm{Zn}-\mathrm{Pa}$, and $\mathrm{Cu}-\mathrm{Pa}$ were observed at $664 \mathrm{~nm}, 653 \mathrm{~nm}$ and $649 \mathrm{~nm}$, respectively.

Table 1. Absorption and fluorescence peak data for Cla, Clb and Cla Derivatives in chloroform.

\begin{tabular}{|c|c|c|c|}
\hline & \multicolumn{2}{|c|}{ Absorption } & \multirow{2}{*}{$\begin{array}{c}\text { Fluorescence } \\
\text { peak }(\mathrm{nm})\end{array}$} \\
\hline & $\begin{array}{c}\text { Soret } \\
\text { peak }(\mathrm{nm}) \\
\end{array}$ & $\begin{array}{c}\begin{array}{c}\text { Q peak } \\
(\mathrm{nm})\end{array} \\
\end{array}$ & \\
\hline Cla & 411 & 663 & 672 \\
\hline $\mathrm{Clb}$ & 423 & 659 & 669 \\
\hline Pheo-a & 421 & 664 & 673 \\
\hline $\mathrm{Cu}-\mathrm{Pa}$ & 414 & 649 & 667 \\
\hline $\mathrm{Zn}-\mathrm{Pa}$ & 420 & 653 & 662 \\
\hline
\end{tabular}


The fluorescence peaks of Cla, Clb, and all CDs exhibited in the range of 660-673 nm (Table 1). It was observed that the position of fluorescence peaks is slightly shifted. According to Figure 5, the Cla and Clb exhibited a higher fluorescence intensity than other CDs. The low fluorescence intensity of other CDs might be due to the Intersystem Crossing reaction (ISC) from their excited state. The ISC reaction that happened in the CDs hopefully can induce the formation of ${ }^{1} \mathrm{O}_{2}$.

The synthesized CDs were treated to the bacterial suspension to understand the effect of the sample for bacterial inhibition. In this study, the non-pathogenic Gram-positive bacteria, $S$. aureus was used as the testing bacteria. The tested compounds+ bacteria colony were irradiated with short wavelength energy (sodium lamp) at $650 \mathrm{~nm}$ since it has low level of harm to the human tissue and also considerably low in price. During the treatment, oxygen was supplied since the type II ISC requires enough $\mathrm{O}_{2}$ to optimize the ${ }^{1} \mathrm{O}_{2}$ formation. The dark toxicity was measured to understand the potency of the tested samples to inhibit the bacterial growth without irradiation. Clb was not included in bioactivity test due to lack of amount and photostability issue. Tween $801 \%$ was used as a surfactant to help immobilization of CDs to the bacterial.

The effect of CDs on bacterial growth was described in the Figure 6. All of CDs showed a dark toxicity potency as shown the bacterial inhibition even without irradiation. The number of bacteria for $\mathrm{Cla}$ and $\mathrm{Zn}-\mathrm{Pa}$ without irradiation was observed at $1.02 \times 10^{7}$ and $1 \times 10^{7}$ $(\mathrm{CFU} / \mathrm{mL})$, respectively. After irradiation, the number of bacteria decreased to $9 \times 10^{6}$ and the $\mathrm{Zn}-\mathrm{Pa}$ presented the promising effect by inhibiting the bacterial growth as the number of bac-

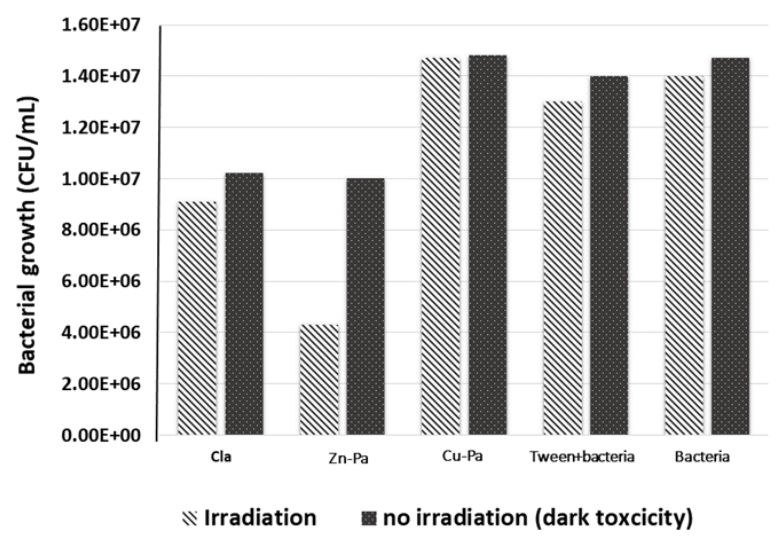

Figure 6. The PDI effect on the bacterial growth. The bioactivity test was conducted by both irradiation and no-irradiation method. teria becomes $4.3 \times 10^{6}$ after irradiation. That result indicates the potency of $\mathrm{Zn}-\mathrm{Pa}$ as a photosensitizer for PDI.

There is no significant effect showed by Cla for irradiated and non-irradiated photosensitizer as shown in the Figure 7. Inhibition activity againts of $S$. aureus for irradiated Cla was $30 \%$, just slightly higher from non-irradiated Cla which exhibited $27 \%$ of inhibition activity. Effect of irradiation on inhibition of $S$. aureus was shown by $\mathrm{Zn}-\mathrm{Pa}$. Irradiated $\mathrm{Zn}-\mathrm{Pa}$ was able to suppress $66.8 \%$ of bacterial growth while non-irradiated $\mathrm{Zn}-\mathrm{Pa}$ just showed $28 \%$ of growth inhibition. The ability of Cla and $\mathrm{Zn}-\mathrm{Pa}$ to inhibit $S$. aureus growth even in dark conditions showed their dark toxicity potency of both compounds. $\mathrm{Cu}-\mathrm{Pa}$ didn't show any inhibition at the radiated and non-radiated condition.

Figure 7 described the inhibition rate of $S$. aureus after treated with CDs with irradiation and without irradiation. The unique behavior was observed in $\mathrm{Cu}-\mathrm{Pa}$, as it does not show any toxicity even and after radiation. The low fluorescence intensity of $\mathrm{Cu}-\mathrm{Pa}$ was contradictory with its bioactivity. Non-toxic properties of $\mathrm{Cu}$ $\mathrm{Pa}$ might be because of copper due to its paramagnetism that favors the deactivation of the excited states, decreasing the production ${ }^{1} \mathrm{O}_{2}$ [25]. Moreover, the absence of dark toxicity of $\mathrm{Cu}-\mathrm{Pa}$ might be due to low microbial uptake. Otherwise, these hypotheses need to be confirmed by further analysis such as the quantum yield of ${ }^{1} \mathrm{O}_{2}$ and cellular uptake measurement.

The finding of this study indicated that the modification of the metal ion center of porphyrin-based compounds influences the physicochemical properties of $\mathrm{CDs}$, while maintaining or even improve their biological activity. A study by Rahimi et al. [36] stated zinc porphyrin complex (ZnTNPP) showed the improvement of photostability properties while main-

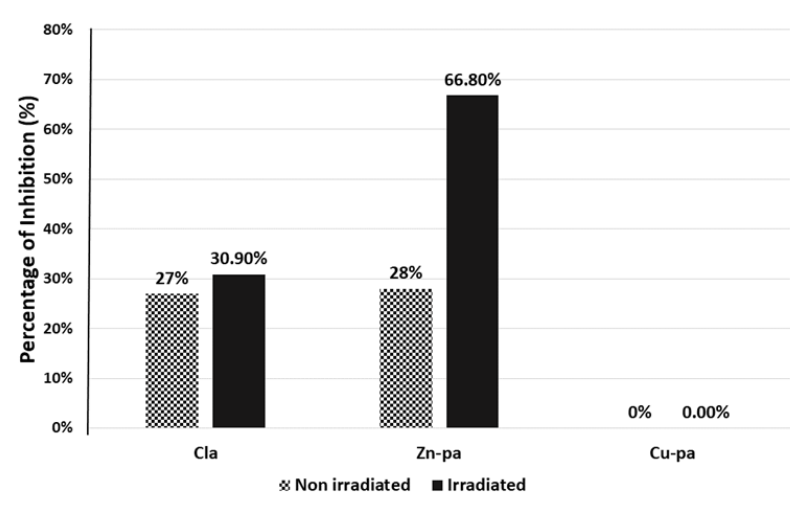

Figure 7. Growth inhibition rate of CDs against $S$. aureus. 
taining the inhibition activity of $P$. aeruginosa. Zoltan et al. [37] described improvement of the biological activity of metal-based porphyrin compared to the metal-free porphyrin is because the role of metal ion to the primordial factor to interfere the spin-orbital coupling as the consequence of the multiple polarisable electron shells and a high nuclear charge density. The change in the sin-orbital coupling thus affects the many physicochemical properties such as, absorption, and fluorescence intensity, energy transfer at the triplet state, and production of singlet oxygen species. That study also showed an efficient inactivation of $E$. coli when it was treated by meso-tetra(pyren-1yl)porphyrin complexes of $\mathrm{Ni}(\mathrm{II}), \mathrm{Cu}(\mathrm{II})$, and $\mathrm{Zn}$ [37].

Even though this study showed a promising photosensitizer candidate among the tested CDs, the further advanced studies are still necessary to be conducted in the future. This will cover several advanced measurements such as are ${ }^{1} \mathrm{O}_{2}$ quantification, photobleaching analysis, and microbial uptake that provide a comprehensive understanding of PDI mechanism in inhibiting the bacterial growth. Moreover, the targeted delivery of the photosensitizer is also needed to be concerned for the proper accumulation of PS in the target infected cells. Proper accumulation in the infected cells is important in order to gain effective treatment without causing any harm to the healthy cells. The targeted delivery of photosensitizer could be accomplished by conjugation with antibodies, synthesis of molecules with a specific structure or attached with the magnetic nanoparticles [2].

\section{Conclusions}

Chlorophyll-a was isolated successfully isolated from raw spinach leaves by the formation of complex precipitate between chlorophyll and 1,4 dioxane then followed by the sucrose gravity column. Natural chlorophyll-a derivatives (CDs) were obtained by introducing the $\mathrm{Zn}^{2+}$ and $\mathrm{Cu}^{2+}$ ions into the pheophytin-a porphyrin ring. Absorption and fluorescence spectra of CDs exhibited favorable physicochemical properties as photosensitizer. $\mathrm{Zn}-\mathrm{Pa}$ displayed a promising candidate as a photosensitizer for PDI as it reduced the number of bacteria by $66.8 \%$. Cla showed $30 \%$ bacterial inhibition, while $\mathrm{Cu}-\mathrm{Pa}$ did not show any bacterial inhibition activity. Inactivity of $\mathrm{Cu}-\mathrm{Pa}$ to inhibit the bacterial growth was might be due to the deactivation of the excited states. This study hopefully can bring new insight for developing new and effective PS from naturally occurring com- pounds and their derivatives. Although, some results in this study showed promising result, more advanced studies are necessary to have a better understanding of PDI mechanism in inhibiting bacterial growth. The targeted delivery scheme also is important to be noted for gaining effective and safe PDI treatment.

\section{Acknowledgements}

The authors acknowledge Biochemistry Research Division, Department of Chemisty, Institut Teknologi Bandung for providing the working space during the bioactivity tests. The author also thanks to School of Life Sciences and Technology, Institut Teknologi Bandung for providing the tested bacteria. This work was supported in part by the Riset dan Inovasi ITB 2020.

\section{References}

[1] Almeida Da Silva, P.E., Palomino, J.C. (2011). Molecular basis and mechanisms of drug resistance in Mycobacterium tuberculosis: classical and new drugs. Journal of Antimicrobial Chemotherapy, 66(7), 1417-1430, doi: 10.1093/jac/dkr173

[2] Amos-Tautua, B.M., Songca, S.P., Oluwafemi, O.S. (2019). Application of Porphyrins in Antibacterial Photodynamic Therapy. Molecules. 24(13), 2456, doi: 10.3390/molecules24132456

[3] Hamblin, A.M.R., Jori, G. (2011). Photodynamic Inactivation of Microbial Pathogens Medical and Environmental Applications: Light Strikes Back Microorganisms in the New Millennium. Photochemistry and Photobiology, 87(6), 1479-1479, doi: 10.1111/j.17511097.2011.01010.x

[4] Wise, R. (2011). The urgent need for new antibacterial agents. Journal of Antimicrobial Chemotherapy, 66(9), 1939-1940, doi: 10.1093/jac/dkr261

[5] Hamblin, M.R., Jori, G., Hader, D.P. (2011). Photodynamic Inactivation of Microbial Pathogens: Medical and Environmental Applications. Comprehensive Series in Photochemistry and Photobiology, 11, 434, doi: 10.1111/j.1751-1097.2011.01010.x

[6] Liu, Y., Qin, R., Zaat, S.A.J., Breukink, E., Heger, M. (2015). Antibacterial photodynamic therapy: overview of a promising approach to fight antibiotic-resistant bacterial infections. Journal of Clinical and Translational Research, 1(3), 140-167, doi : $10.18053 /$ jctres.201503.002 
[7] Tim, M. (2015). Biology Strategies to optimize photosensitizers for photodynamic inactivation of bacteria. Journal of Photochemistry \& Photobiology B, 150, 2-10, doi: 10.1016/j.jphotobiol.2015.05.010

[8] Maisch, T., Eichner, A., Späth, A., Gollmer, A., König, B., Regensburger, J., Bäumler, W. (2014). Fast and effective photodynamic inactivation of multiresistant bacteria by cationic riboflavin derivatives. PLoS ONE, 9(12), 1-8, doi: 10.1371/journal.pone.0111792

[9] Ghorbani, J., Rahban, D., Aghamiri, S., Teymouri, A., Bahador, A. (2018). Photosensitizers in antibacterial photodynamic therapy: an overview. Laser therapy, 27(4), 293-302, doi: 10.5978/islsm.27_18-RA-01

[10] Nitzan, Y., Gutterman, M., Malik, Z., Ehrenberg, B. (1992). Inactivation of Gram-Negative Bacteria By Photosensitized Porphyrins. Photochemistry and Photobiology, 55(1), 89-96, doi: 10.1111/j.17511097.1992.tb04213.x

[11] Castano, A.P., Demidova, T.N., Hamblin, M. (2004). Mechanisms in photodynamic therapy: part one. Photodiagnosis Photodyn Ther, 1(4), 279-293, doi: 10.1016/S1572-1000(05)00007-4

[12] Mojzisova, H., Bonneau, S., Brault, D. (2007). Structural and physico-chemical determinants of the interactions of macrocyclic photosensitizers with cells. European Biophysics Journal, 36(8), 943-953, doi: 10.1007/s00249007-0204-9

[13] Stepp, H., Waldelich, R. (2007). Fluoreszenzdiagnostik und Photodynamische Therapie in der Urologie. Aktuelle Urologie, 38(6), 455-464, doi: 10.1055/s-2007-980149

[14] MacRobert, A.J., Bown, S.G., Phillips, D. (1989). What are the ideal photoproperties for a sensitizer?. Ciba Foundation Symposium, 146, 4-16, doi: 10.1002/9780470513842.ch2

[15] Macdonald, I.A.N.J., Dougherty, T.J. (2008). MacDonald2007. Basic principles of photodynamic therapy. Journal of Porphyrins and Phthalocyanines, 5, 1-18, doi: 10.1002/jpp.328

[16] Jori, G., Fabris, C., Soncin, M., Ferro, S., Coppellotti, O., Dei, D., Fantetti, L., Chiti, G., Roncucci, G. (2006). Photodynamic therapy in the treatment of microbial infections: Basic principles and perspective applications. $L a$ sers in Surgery and Medicine, 38(5), 468-481, doi: 10.1002/lsm.20361

[17] Kashef, N., Hamblin, M.R. (2017). Can microbial cells develop resistance to oxidative stress in antimicrobial photodynamic inactivation?. Drug Resistance Updates, 31, 31-42, doi: 10.1016/j.drup.2017.07.003
[18] Benov, L., Craik, J., Batinic-Haberle, I. (2012). The Potential of $\mathrm{Zn}(\mathrm{II}) \mathrm{N}$ Alkylpyridylporphyrins for Anticancer Therapy. Anti-Cancer Agents in Medicinal Chemistry, 11(2), 233-241, d o i : 10.2174/187152011795255975

[19] Al-mutairi, R., Tovmasyan, A., Batinichaberle, I., Benov, L. (2018). Sublethal Photodynamic Treatment Does Not Lead to Development of Resistance. Frontier in Microbiology, 9, 1699, doi: 10.3389/fmicb.2018.01699

[20] Lammer, A.D., Cook, M.E., Sessler, J.L., Phthalocyanines, J.P. (2015). Synthesis and anti-cancer activities of a water soluble gold (III) porphyrin. Journal of Porphyrins and Phthalocyanines, 19, 1-6, doi: 10.1142/S1088424615500236

[21] Abrahamse, H., Hamblin, M.R. (2016). New photosensitizers for photodynamic therapy. Biochemical Journal, 473, 347-364, doi: 10.1042/BJ20150942

[22] Kou, J., Dou, D., Yang, L. (2017). Porphyrin photosensitizers in photodynamic therapy and its applications. Oncotarget, 8(46), 81591-81603, doi: 10.18632/oncotarget.20189

[23] Nyman, E.S., Hynninen, P.H. (2004). Research advances in the use of tetrapyrrolic photosensitizers for photodynamic therapy. Journal of Photochemistry and Photobiology B: Biology, 73(1-2), 1-28, doi: 10.1016/j.jphotobiol.2003.10.002

[24] Berezin, B.D., Berezin, M.B., Moryganov, A.P., Rumyantseva, S.V., Dymnikova, N.S. (2003). Chlorophyll and its derivatives, chlorins and porphyrins, as a promising class of environmentally friendly dyes. Russian Journal of Applied Chemistry, 76(12), 1958-1961, doi: 10.1023/B:RJAC.0000022447.81026.1a

[25] Gerola, A.P., Santana, A., Franc, P.B., Tsubone, T.M., Oliveira, H.P M.De, Caetano, W., Kimura, E., Hioka, N., Camilo, U., Branco, C., Jose, S. (2011). Effects of Metal and the Phytyl Chain on Chlorophyll Derivatives: Physicochemical Evaluation for Photodynamic Inactivation of Microorganisms. Photochemistry and Photobiology, 87, 884-894, doi: 10.1111/j.1751-1097.2011.00935.x

[26] Allison, R.R., Downie, G.H., Cuenca, R., Hu, X., Childs, C.J.H., Sibata, C.H. (2004). Photosensitizers in clinical PDT. Photodiagnosis and Photodynamic Therapy, 1, 7-9, doi: 10.1016/S1572-1000(04)00007-9

[27] Alves, E., Faustino, M.A.F., Neves, M.G.P.M.S., Cunha, A., Tome, J., Almeida, A. (2014). An insight on bacterial cellular targets of photodynamic inactivation. Future $\mathrm{Me}$ dicinal Chemistry, 6(2), 141-164, doi: 10.4155/fmc. 13.211 
[28] Josefsen, L.B., Boyle, R.W. (2008). Photodynamic therapy and the development of metalbased photosensitisers. Metal-Based Drugs, 2008, 276109, doi: 10.1155/2008/276109

[29] Felsher, D.W. (2003). Cancer revoked: Oncogenes as therapeutic targets. Nature Reviews Cancer, 3(5), 375-380, doi: 10.1038/nrc1070

[30] Nurhayati, N., Suendo, V. (2011). Isolation of Chlorophyll a from Spinach Leaves and Modification of Center Ion with $\mathrm{Zn}^{2+}$ : Study on its Optical Stability. Jurnal Matematika dan Sains, 16(2), 65-70.

[31] Pareek, S., Sagar, N.A., Sharma, S., Kumar, V., Agarwal, T., González-Aguilar, G.A., Yahia, E.M. (2017). Chlorophylls: Chemistry and biological functions. In: Yahia, E.M. (Ed.). Fruit and Vegetable Phytochemicals: Chemistry and Human Health: Second Edition. John Wiley \& Sons Ltd., 269-284, doi: 10.1002/9781119158042.ch14

[32] Inoue, H., Imai, M., Naemura, T. (1993). Preparation and determination of zinc (II) chlorophylls by reversed-phase highperformance liquid chromatography. Journal of Chromatography, 645, 259-264, doi: 10.1016/0021-9673(93)83385-6

[33] Ioka, N.O.H., Imura, E.L.Z.A.K. (2008). Photodynamic effect of light emitting diode light on cell growth. Journal of Bioscience, 33, 231237, doi: 10.1007/s12038-008-0040-9
[34] Croft, H., Chen, J.M. (2017). Leaf pigment content. In Comprehensive Remote Sensing (Vols. 1-9, Issue October). Elsevier Inc., doi: 10.1016/B978-0-12-409548-9.10547-0

[35] Sandiningtyas, R.D., Suendo, V. (2010). Isolation of Chrlorophyll-a from Spinach and Its Modification using $\mathrm{Fe}^{2+}$ in Photostability Study. Third International Conference on Mathematics and Natural Science (ICMNS 2010). 859-873.

[36] Rahimi, H.R., Fayyaz, F., Rassa, M., Rabbani, M. (2018). Microwave-assisted synthesis of 5,10,15,20-tetrakis(4-nitrophenyl) porphyrin and zinc derivative and study of their bacterial photoinactivation. Iranian Chemical Communication Payame Noor University, 6(21), $\begin{array}{llllllll}3 & 0 & 0 & - & 3 & 1 & 1 & \end{array}$, http://icc.journals.pnu.ac.ir/mobile/article_193 5_cb24098fd616dfbce9f734c2f2b19b67.pdf

[37] Zoltan, T., Vargas, F., Rivas, C., López, V., Perez, J., Biasutto, A. (2010). Synthesis, photochemical and photoinduced antibacterial activity studies of meso-tetra(pyren-1yl)porphyrin and its $\mathrm{Ni}, \mathrm{Cu}$ and $\mathrm{Zn}$ complexes. Scientia Pharmaceutica, 78(4), 767-789, doi: $10.3797 /$ scipharm.1003-13

Selected and Revised Papers from $3^{\text {rd }}$ International Conference on Chemistry, Chemical Process and Engineering 2020 (IC3PE 2020) (https://chemistry.uii.ac.id/ic3pe/) (Universitas Islam Indonesia (UII), Labuan Bajo, Nusa Tenggara Timur, Indonesia by 30th September - $1^{\text {st }}$ October 2020) after Peer-reviewed by Scientific Committee of IC3PE 2020 and Peer-Reviewers of Bulletin of Chemical Reaction Engineering \& Catalysis. Editors: I. Istadi; Is Fatimah 